\title{
A comprehensive study of Weighted Product Model for selecting the best laptop model available in the market
}

\author{
Shankha Shubhra Goswami ${ }^{1}$ Dhiren Kumar Behera1, Soupayan Mitra² \\ ${ }^{1}$ Indira Gandhi Institute of Technology, Department of Mechanical Engineering, Sarang, Dhenkanal, Odisha, India. \\ `Jalpaiguri Government Engineering College, Department of Mechanical Engineering, Jalpaiguri, West Bengal, India.
}

How to cite: Goswami, S.S., Behera, D.K. and Mitra, S. (2020), "A comprehensive study of Weighted Product Model for selecting the best laptop model available in the market", Brazilian Journal of Operations \& Production Management, Vol. 17, No. 2, e2020875. https://doi.org/10.14488/BJOPM.2020.017

\section{ABSTRACT}

Goal: the main objective of this research paper is to select the best laptop model among 6 models actually available in the market by applying multiple criteria decision making methodology (MCDM) on the basis of a physical market survey and opinions of 100 people specially consists of students. Since, choosing an appropriate laptop model among thousands of different available models is quite a challenging task for the students.

Design / Methodology / Approach: for this present analysis, a combined approach of analytic hierarchy process (AHP) and weighted product model (WPM) is developed. Where, AHP is used to calculate the criteria weightages and WPM is used to choose the best option and to rank the alternatives. The selection process is done based on the following seven important criteria of the laptop i.e. processor, hard disk capacity, operating system, RAM, screen size, brand, color.

Results: The final outcome result shows that Model 5 is the best choice among these 6 models followed by Model 3 and Model 2 whereas model 4 is the worst one among them. The specifications of the best laptop model 5 among this group are having 15 processor, 1TB hard disk capacity, windows operating system, 8GB RAM, 15.6-inch display, HP brand and color silver.

Limitations of the investigation: Since the weightages calculation and the final ranking mainly depends on the structure of the pair-wise comparison matrix and the decision matrix, so the final results may vary based on the opinion of the other decision maker. Moreover, if the same problem is solved by applying other MCDM tools, the final output results may or may not be same.

Practical implications: From this present research work, students who are willing to buy a laptop can get a general guideline about the best laptop model and their specifications in the present market. Moreover, the laptop manufacturing companies can also get some ideas about the present market scenario since this analysis is based on the actual market survey which can help to frame their future strategies.

Originality / Value: Although, many literatures have been recorded related to the applications of MCDM tools in solving different decision making problems in different areas but very limited research work have been done in solving our daily life decision problems by applying MCDM.

Keywords: Decision Analysis; Multi Criteria Decision Making (MCDM); Weighted Product Model (WPM); Analytic Hierarchy Process (AHP); Laptop Model.

\section{INTRODUCTION}

Laptop computers is a basic need in our daily life and it became an important essential electronic gadget in the fields of education (Mitra and Goswami, 2019a, p. 784), business, medical etc. so choosing a suitable laptop model for particular field of applications is very

\section{Financial support: None.}

Conflict of interest: The authors have no conflict of interest to declare.

Corresponding author: shankhashubhragoswami@gmail.com

Received: 10 July 2019.

Approved: 10 Feb 2020.

Editor: Osvaldo L. G. Quelhas.

(4) This is an Open Access article distributed under the terms of the Creative Commons Attribution License, which permits unrestricted use, This is an Open Access article distributed under the terms of the Creative Commons Attrib
distribution, and reproduction in any medium, provided the original work is properly cited. 
much essential. Sometimes it's very hard to select the appropriate laptop model based on our requirements that properly matches with our professions. There are lots of different models available in the market, so it is very difficult to select the appropriate one among these models. Moreover, one may fail to get all the desired specifications in one model, to get rid of this confusing situations, MCDM methodologies (Salomon and Whitaker, 2007) provides a way to the decision makers to select the right choices having different conflicting criteria (Cavalcante and Costa, 2010; Triantaphyllou and Mann, 1995) among different available alternatives. This research paper mainly highlighted the best laptop model selection process suitable for the students since their opinions are mostly taken through a physical market survey and it is obviously very necessary to choose the appropriate laptop among thousands of different models available in the market (Adali and Işık, 2017).

From the past studies, several researchers have adopted different multi-criteria decision support tools (Araujo et al., 2017) e.g. The Technique for Order of Preference by Similarity to Ideal Solution (TOPSIS) (Hwang and Yoon, 1981), ELimination Et Choix Traduisant la REalité (ELECTRE) (Costa et al., 2018; Roy, 1968), data envelopment analysis (DEA) (Climaco et al., 2010), simple additive weighting (SAW) (Fishburn, 1967; MacCrimon, 1968; Triantaphyllou and Mann, 1989), VIseKriterijuska Optimizacija I Komoromisno Resenje (VIKOR) (Duckstein and Opricovic, 1980) etc. in different field of applications e.g. project analysis (Saisse and Lima, 2019), business and financial sector (Nery, 2017; Salomon and Whitaker, 2007), educational sectors (Donizetti de Lima et al., 2017; Endler et al., 2017), global suppliers network development and logistics (Grillo et al., 2018; Resende de Carvalho et al., 2017), water management (Costa and Amato Neto, 2017), supply chain management (Reis et al., 2017) etc. for strategic decision making (Moraes Vieira et al., 2017). With the rapid development of computer technology in recent few years, multi criteria decision making (MCDM) techniques also gaining its importance and serves as an effective tool for analyzing complex decision making problems (Karande et al., 2016). MCDM methodologies also find its own importance in industrial sectors, e.g. Afshari et al. (2010), applied simple additive weighting approach for the personnel selection problem in their research work. Ayhan (2013), implemented Fuzzy-AHP for supplier selection in a gearmotor company and later Venkateswarlu and Sarma (2016), implemented SAW and VIKOR techniques for the selection of suppliers. Bose and Chatterjee (2016) selected the wind turbine service technicians by applying a hybrid concept of fuzzy MOORA and fuzzy ARAS methodology. Işık and Adali (2016) used TOPSIS method for solving a tractor selection problem. Santis et al. (2017) considered a case study from a Brazilian railway operator for the selection of supplier using fuzzy analytic hierarchy process. Sari et al. (2018), developed a combined approach of Fuzzy-AHP and TOPSIS for evaluating the performance of the raw material suppliers based on five criteria, i.e., price, quality, delivery, flexibility, and service. Fuzzy-AHP is adopted for finding the weightages of each criterion and finally TOPSIS is applied for the ranking of all alternatives. The final output results for the best suppliers of raw materials are LI, PA, and SL for fabrics, dyes, and wax respectively. Marzouk and Abdelakder (2019) presented an approach to minimize the environmental emissions in construction projects by applying TOPSIS, COPRAS and weighted sum model (WSM).

The application of MCDM methodologies is not only restricted within the scope of industrial sector (Lee et al., 2008; Duran and Aguilo, 2008; Karande et al., 2016), energy sector (Kowalski et al., 2009; Tsoutsos et al., 2009), environmental issues (Geldermann et al., 2000; Vaillancourt and Waaub, 2004; Qin et al., 2008), logistics and supply chain management (Hernandez et al., 2010; Hofmann, 2011) but also, some researchers find it suitable for selecting the best products, processes, strategies associated with our daily life, for example Mitra and Kundu (2017) applied AHP for the best domestic refrigerator selection and further Mitra and Kundu (2018) also analyzed the same problem by applying TOPSIS. The best-chosen refrigerator model is coming out to be Model 2 in both the cases, however there is a slight change in ranking of the refrigerator models between these two techniques. Mitra and Goswami (2019a), also implemented the combined approach of AHP-TOPSIS in the selection of best desktop model among 5 alternatives based on five criteria i.e. processor, hard disk 
capacity, RAM, brand, screen size and further, Mitra and Goswami (2019b) also analyzed the same problem by SAW methodology using the same weightages found out by AHP.

From the above literature it can be seen that most of the researchers adopted and applied different MCDM tools for taking effective decisions related to different industry e.g. manufacturing industry (Dey and Chakraborty, 2016; Prasad and Chakraborty, 2018), textile industry (Kundakci and Tuş Işık, 2016), project management and evaluation (Chaghooshi et al., 2016; Rathi et al., 2016), supplier selection problems (Prasad et al., 2017; Koganti et al., 2019), transportation and logistics (Tzeng et al., 2005; Efendigil et al., 2008), energy sector (Kowalski et al., 2009; Tsoutsos et al., 2009) etc. but very few research works have been recorded where MCDM tools are applied for taking strategic decisions while purchasing some household appliances which are related to our daily life problems like choosing of an appropriate electronic gadgets e.g. washing machine, mobile (Goswami and Mitra, 2020), refrigerator (Mitra and Kundu, 2017; 2018), computers (Mitra and Goswami, 2019a; 2019b), air conditioner (Adali and Işı, 2016) etc. choosing a four-wheeler or a two-wheeler (Sri Krishna et al., 2014; Biswas and Saha, 2019). The initiative to fill this research gap have been taken in this research work by choosing the best laptop model among 6 available alternatives which is the main objective of this research. This research work might provide some basic idea to the students while purchasing a laptop computer since this paper involves the present market conditions and also the opinion of the other students about a laptop.

In this paper, a combined hybrid (Costa, 2017) approach of analytic hierarchy process (AHP) (Quezada et al., 2006; Saaty, 1980) and weighted product model (WPM) (Miller and Starr, 1969; Triantaphyllou and Mann, 1989) is implemented for the selection of the best laptop model among 6 models available in the market. For this analysis 7 important criteria (laptop specification) are considered i.e. processor, hard disk capacity, operating system, RAM, screen size, color, brand. The present investigation involves the market survey of 100 people (which mainly consists of students) to know their relative choices and preferences regarding the criteria and sub-criteria and based on this survey the whole analysis is carried out. The weightages of each criterion are found out by applying Analytic Hierarchy Process (AHP) (Saaty, 1980; 2008) and these weightages are utilized in WPM method to find out relative weightages of all alternatives showing the choices of preferences of one alternative over another. Also, this analysis makes a ranking order of all the laptop models showing from the best to worst model.

\section{THEORETICAL ANALYSIS}

The detailed steps of analytic hierarchy process (AHP) and weighted product model (WPM) are described in the next section.

\section{Analytic hierarchy process (AHP)}

Analytic Hierarchy Process is decision making technique developed by Thomas L. Saaty (1980; 2008) in 1970s. AHP breaks the objective goal into hierarchies and form a pair-wise comparison among the criteria which leads to the weightage calculation of each criteria. It is widely used in the field of education (Melon et al., 2008), business and finance (Wu et al., 2009), healthcare (Podgorski, 2015), shipbuilding (Kandakoglu et al., 2009; Saracoglu, 2013) etc. to take complex decisions and to select the best process and strategies. The details of AHP are shown step by step below. 
Step 1: Construction of hierarchy tree showing all the criteria and sub-criteria as shown below in Figure 1.

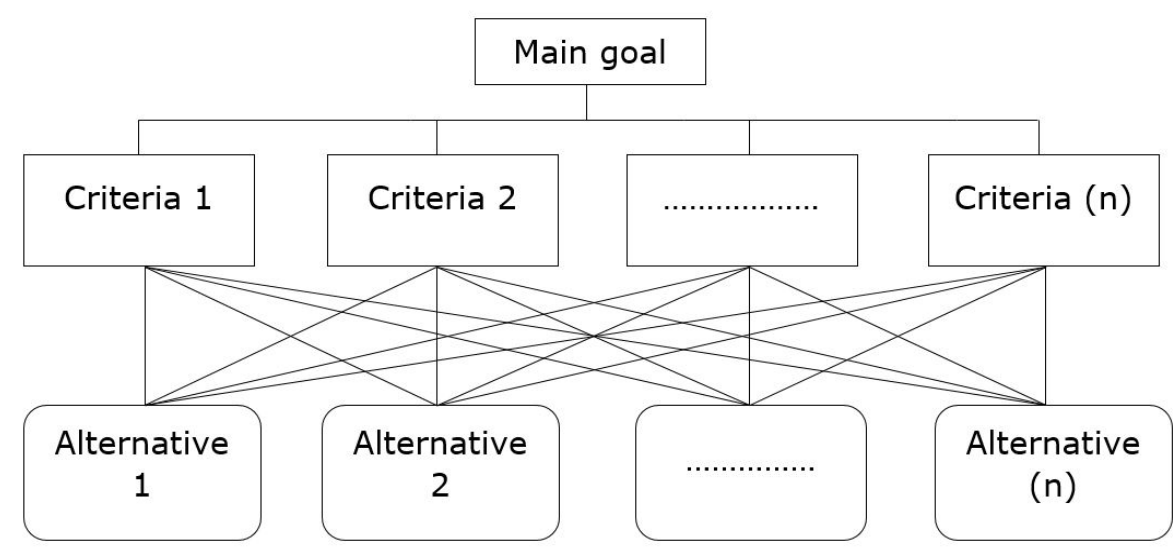

Figure 1: Structural hierarchy tree of AHP Source: The author(s) himself

Step 2: A pair-wise comparison matrix $\left(n_{i} \times n_{j}\right)$ as shown in Equation 1 is created based on the market views of the customers according to Satty's scale (Saaty, 1980). Saaty's 9 pair comparison scale is shown in Table 1. Where, $n_{i}=n_{j}$

$$
A\left(n_{i}^{*} n_{j}\right)=\left[\begin{array}{cccccc}
a_{11} & a_{12} & a_{13} & a_{14} & \ldots & a_{1 n} \\
a_{21} & a_{22} & a_{23} & a_{24} & \ldots & a_{2 n} \\
a_{31} & a_{32} & a_{33} & a_{34} & \ldots & a_{3 n} \\
a_{41} & a_{42} & a_{43} & a_{44} & \ldots & a_{4 n} \\
\ldots & \ldots & \ldots & \ldots & \ldots & \ldots \\
a_{n 1} & a_{n 2} & a_{n 3} & a_{n 4} & \ldots & a_{n n}
\end{array}\right]
$$

Step 3: Normalization of the pair-wise comparison matrix is done by using Equation 2 below.

$$
N_{i j}=a_{i j} / \sum_{i=1}^{n} a_{i j}
$$

$\mathrm{i}=1,2,3 \ldots \mathrm{n}$

$j=1,2,3 \ldots . n$

Step 4: Calculate the weightages of each criterion by using Equation 3 and create a priority vector matrix as shown in Equation 4. The weightages are also called the priority vector.

$w_{j}=\frac{\sum_{j=1}^{n} N_{i j}}{n}$

$\mathrm{i}=1,2,3 \ldots \mathrm{n}$

$j=1,2,3 \ldots . n$ 
$W_{j}=\left[\begin{array}{c}w_{1} \\ w_{2} \\ w_{3} \\ w_{4} \\ \cdots \\ w_{n}\end{array}\right]$

Step 5: Consistency calculation of each criteria.

The priority vector matrix and the pairwise comparison matrix is multiplied to find out the weighted sum matrix as shown by Equation 5 and Equation 6.

$W_{s}=W_{j} * A$

$W_{s}=\left[\begin{array}{c}w_{1} \\ w_{2} \\ w_{3} \\ w_{4} \\ \ldots \\ w_{n}\end{array}\right] *\left[\begin{array}{cccccc}a_{11} & a_{12} & a_{13} & a_{14} & \ldots & a_{1 n} \\ a_{21} & a_{22} & a_{23} & a_{24} & \ldots & a_{2 n} \\ a_{31} & a_{32} & a_{33} & a_{34} & \ldots & a_{3 n} \\ a_{41} & a_{42} & a_{43} & a_{44} & \ldots & a_{4 n} \\ \ldots & \ldots & \ldots & \ldots & \ldots & \ldots \\ a_{n 1} & a_{n 2} & a_{n 3} & a_{n 4} & \ldots & a_{n n}\end{array}\right]$

Each element of the weighted sum matrix $\left(W_{s}\right)$ is divided by their respective priority vector $\left(w_{j}\right)$ to find out the consistency of each criterion. Now calculate the average of all the consistencies to obtain the value of average consistency $\lambda_{\max }$.

Step 6: Calculate the consistency index $(\mathrm{Cl})$ and the consistency ratio (CR).

consistency index $(\mathrm{Cl})$ and consistency ratio (CR) is calculated by using Equation 7 and Equation 8 shown below.

Consistency Index $(\mathrm{Cl})=\left(\lambda_{\max }-n\right) /(n-1)$

Where, $\mathrm{n}$ is the order of Matrix

Consistency Ratio $(\mathrm{CR})=\mathrm{Cl} / \mathrm{RI}$

Where RI is the Randomly Generated Index shown in Table 2.

Now, if the consistency ratio (CR) is less than 0.1 then the judgement of the decision maker is acceptable and the pair-wise comparison matrix is consistent (Costa, 2011). If the value of $C R$ is greater than 0.1 then the pair-wise comparison matrix needs to be modified and the consistency is again checked whether the CR ratio is restricted within 10\% or not after the modification. According to Saaty (Saaty, 1980) up to 10\% of inconsistency (Costa, 2011) can be allowed in this type of decision making problem so the CR ratio needs to be limited within 0.1 or $10 \%$. 
Table 1: Saaty's 9 pair Linguistic Scale (Saaty, 1980)

\begin{tabular}{cc}
\hline $\begin{array}{c}\text { Saaty's pair wise } \\
\text { comparison scale }\end{array}$ & $\begin{array}{c}\text { Compare factor } \\
\text { of } \mathbf{i} \boldsymbol{\&} \mathbf{j}\end{array}$ \\
\hline 1 & Equal Importance \\
\hline 3 & Moderate Importance \\
\hline 5 & Strong Importance \\
\hline 7 & Very Strong or Demonstrated Importance \\
\hline 9 & Extreme Importance \\
\hline $2,4,6,8$ & Intermediate values when compromise is needed \\
\hline
\end{tabular}

Source: Saaty (1980)

Table 2: Randomly Generated Index Value (RI)

\begin{tabular}{|c|c|c|c|c|c|c|c|c|c|c|c|c|}
\hline $\mathrm{n}$ & 1 & 2 & 3 & 4 & 5 & 6 & 7 & 8 & 9 & 10 & 11 & 12 \\
\hline RI & 0 & 0 & 0.58 & 0.9 & 1.12 & 1.24 & 1.32 & 1.41 & 1.45 & 1.49 & 1.51 & 1.58 \\
\hline
\end{tabular}

Source: Saaty (1980)

Saaty compared the consistency index with the appropriate consistency index (which is also known as randomly generated index) and proposed the consistency ratio value. Saaty randomly generated reciprocal matrix using scale $\frac{1}{9}, \frac{1}{8}, \ldots ., 1 \ldots, 8,9$ and get the random consistency index to see if it is about $10 \%$ or less. The average random consistency index of sample size 500 matrices is shown in the above Table 2.

\section{Weighted product model (WPM)}

Weighted product model (WPM) (Bridgman, 1922; Miller \& Starr, 1969; Triantaphyllou \& Mann, 1989) is the extension of the weighted sum model (WSM) (Fishburn, 1967; MacCrimon, 1968; Triantaphyllou \& Mann, 1989; Triantaphyllou, 2000). Each alternative is compared with the other alternatives by multiplying a number of ratios, one for each decision criterion. Each ratio is raised to the power equivalent to the weights of the corresponding criterion (Bridgman, 1922; Miller \& Starr, 1969; Triantaphyllou \& Mann, 1989; Triantaphyllou, 2000; Tofallis, 2014).

Step 1: Forming an evaluation matrix $\left(m_{i} \times n_{j}\right)$ shown by equation 9 according to Hwang and Yoon (1981) comparison scale. Where, $m$ is the number of alternatives and $n$ is the number of criteria. Hwang and Yoon comparison scale are shown in Table 3. Where, $m_{i}=n_{j}$ or $m_{i} \neq n_{j}$.

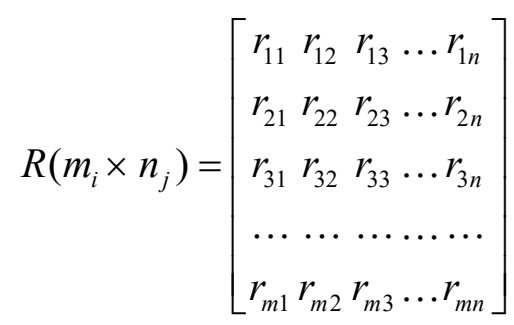

Step 2: The evaluation or the decision matrix is normalized by using Equation 10 or Equation 11 according to the requirements and thus creating the normalization matrix.

a) For positive criteria, (whose larger values is desired)

$$
n_{i j}=\frac{r_{i j}}{r_{j}^{\max }}
$$

Where, $i=1,2,3 \ldots . m$

$\mathrm{j}=1,2,3 \ldots \mathrm{n}$ 
b) For negative or cost criteria, (whose smaller values is desired)

$n_{i j}=\frac{r_{j}^{\min }}{r_{i j}}$

Where, $i=1,2,3 \ldots . m$

$\mathrm{j}=1,2,3 \ldots . \mathrm{n}$

$r_{j}^{\max }=$ Largest number in the column of $\mathrm{j}$

$r_{j}^{\min }=$ Smallest number in the column of $\mathrm{j}$

Step 3: The ratio or the relative weightages is calculated comparing each alternative over another by using Equation 12 .

$P\left(\frac{A_{k}}{A_{l}}\right)=\prod_{j=1}^{n}\left(\frac{n_{k j}}{n_{l j}}\right)^{w_{j}}$

$k, l=1,2,3 \ldots . m$

Let us consider two alternatives $A_{k}$ and $A_{l}$, in case of maximization problem, if $P\left(\frac{A_{k}}{A_{l}}\right)$ is greater than 1 i.e. $P\left(\frac{A_{k}}{A_{l}}\right)>1$ then the alternative $A_{k}$ is better than $A_{l}$ and if $P\left(\frac{A_{k}}{A_{l}}\right)<1$ then $A_{l}$ is better than $A_{k}$.

Table 3: Hwang and Yoon Comparison Scale (Hwang and Yoon, 1981)

\begin{tabular}{ccccccc}
\hline $\begin{array}{l}\text { Qualitative } \\
\text { Estimation }\end{array}$ & Bad & Good & Average & Very Good & Excellent & $\begin{array}{c}\text { Type of } \\
\text { Criteria }\end{array}$ \\
\hline Quantitative & 1 & 3 & 5 & 7 & 9 & Max \\
Estimation & 9 & 7 & 5 & 3 & 1 & Min \\
\hline
\end{tabular}

Source: Hwang and Yoon (1981)

\section{RESEARCH METHODOLOGY}

In this present analysis 7 major laptop specifications (main criteria) are chosen and within the main criteria there are number of sub-criteria. The hierarchy tree of the laptop models is shown in Figure 2. Firstly, AHP is applied to find out the weightages of the main criteria and the consistency is checked for the pair-wise comparison matrix. Finally, these weightages are implemented in WPM method for the final ranking of the alternatives. For this research purposes 6 laptop models are chosen which are actually available in most of the electronic stores and from the survey of some local electronic stores it is found that these 6 models are generally preferred or demanded by maximum customers. The details of 6 laptop models and their specifications are shown in Table 4 . All the detailed calculations are shown in the next section as follows.

Table 4: Laptop Models and their Specifications

\begin{tabular}{cccccccc}
\hline Models & Processor & $\begin{array}{c}\text { Hard Disk } \\
\text { Capacity }\end{array}$ & $\begin{array}{c}\text { Operating } \\
\text { System }\end{array}$ & RAM & Screen Size & Brand & Color \\
\hline Model 1 & 13 & $512 \mathrm{~GB}$ & DOS & $4 \mathrm{~GB}$ & 14 Inch & HP & Black \\
Model 2 & 15 & $1 \mathrm{~TB}$ & Linux & $4 \mathrm{~GB}$ & 15.6 Inch & Acer & Black \\
Model 3 & 15 & $2 \mathrm{~TB}$ & Windows & $8 \mathrm{~GB}$ & 15.6 Inch & Lenovo & Gold \\
\hline Model 4 & 17 & $2 \mathrm{~TB}$ & Windows & $16 \mathrm{~GB}$ & 17.3 Inch & Asus & Silver \\
Model 5 & 15 & $1 \mathrm{~TB}$ & Windows & $8 \mathrm{~GB}$ & 15.6 Inch & HP & Silver \\
\hline Model 6 & 13 & $512 \mathrm{~GB}$ & Linux & $4 \mathrm{~GB}$ & 15.6 Inch & Dell & Black \\
\hline
\end{tabular}




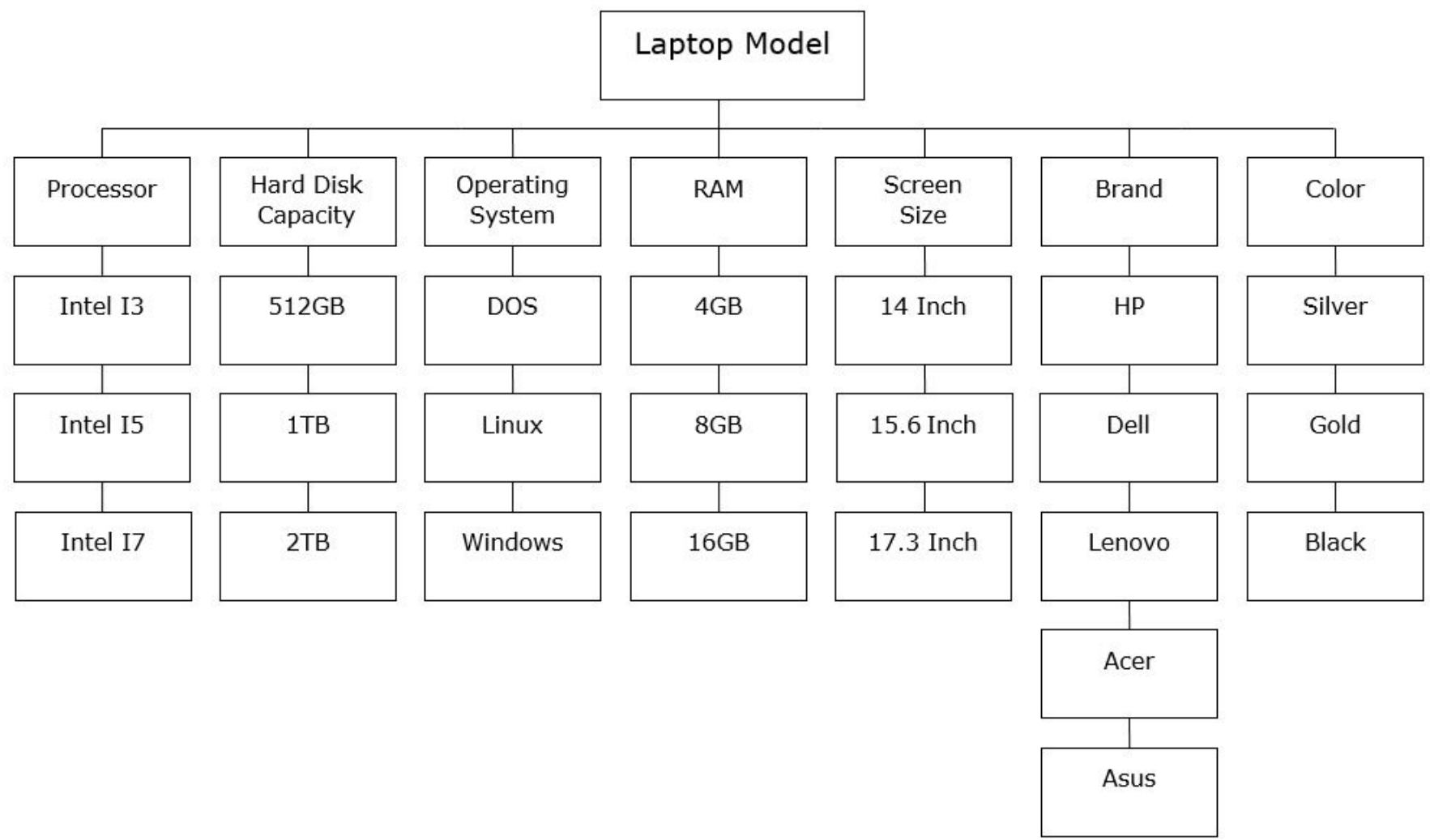

Figure 2: Hierarchy Tree of Laptop Model Showing all Criteria and Sub-criteria Source: The author(s) himself

\section{Calculation details of analytic hierarchy process (AHP)}

Table 5: Pair Wise Comparison Matrix of the Main Criteria

\begin{tabular}{|c|c|c|c|c|c|c|c|}
\hline Comparisons & Processor & $\begin{array}{c}\text { Hard Disk } \\
\text { Capacity }\end{array}$ & $\begin{array}{l}\text { Operating } \\
\text { System }\end{array}$ & RAM & Screen Size & Brand & Color \\
\hline Processor & 1 & 5 & 7 & 3 & 2 & 7 & 9 \\
\hline Hard Disk Capacity & $1 / 5$ & 1 & 3 & $1 / 3$ & $1 / 3$ & 2 & 5 \\
\hline Operating System & $1 / 7$ & $1 / 3$ & 1 & $1 / 5$ & $1 / 3$ & $1 / 3$ & 3 \\
\hline RAM & $1 / 3$ & 3 & 5 & 1 & 2 & 3 & 9 \\
\hline Screen Size & $1 / 2$ & 3 & 3 & $1 / 2$ & 1 & 3 & 7 \\
\hline Brand & $1 / 7$ & $1 / 2$ & 3 & $1 / 3$ & $1 / 3$ & 1 & 5 \\
\hline Color & $1 / 9$ & $1 / 5$ & $1 / 3$ & $1 / 9$ & $1 / 7$ & $1 / 5$ & 1 \\
\hline Total & 2.43015873 & 13.03333333 & 22.33333333 & 5.47777778 & 6.14285714 & 16.53333333 & 39 \\
\hline
\end{tabular}

Source: The author(s) himself

Based on the market survey of 100 laptop users mainly students, the pair-wise comparison matrix is created showing the relative importance of one criterion over another according to saaty's pair-wise comparison scale as shown in Table 1. Table 5 above shows the pair-wise comparison matrix of the main criteria. 
Table 6: Weightage Calculation of the Main Criteria

\begin{tabular}{|c|c|c|c|c|c|c|c|c|c|}
\hline Comparisons & Processor & $\begin{array}{c}\text { Hard Disk } \\
\text { Capacity }\end{array}$ & $\begin{array}{l}\text { Operating } \\
\text { System }\end{array}$ & RAM & $\begin{array}{c}\text { Screen } \\
\text { Size }\end{array}$ & Brand & Color & $\begin{array}{c}\text { Row } \\
\text { Average } \\
\left(w_{\mathrm{j}}\right)\end{array}$ & Weight \% \\
\hline Processor & 0.41149575 & 0.38363171 & 0.31343284 & 0.54766734 & 0.32558140 & 0.42338710 & 0.23076923 & 0.37656648 & 37.656648 \\
\hline $\begin{array}{c}\text { Hard Disk } \\
\text { Capacity }\end{array}$ & 0.08229915 & 0.07672634 & 0.13432836 & 0.06085193 & 0.05426357 & 0.12096774 & 0.12820513 & 0.09394889 & 9.394889 \\
\hline $\begin{array}{l}\text { Operating } \\
\text { System }\end{array}$ & 0.05878511 & 0.02557545 & 0.04477612 & 0.03651116 & 0.05426357 & 0.02016129 & 0.07692308 & 0.04528511 & 4.528511 \\
\hline RAM & 0.13716525 & 0.23017903 & 0.22388060 & 0.18255578 & 0.32558140 & 0.18145161 & 0.23076923 & 0.21594041 & 21.594041 \\
\hline Screen Size & 0.20574788 & 0.23017903 & 0.13432836 & 0.0912779 & 0.16279070 & 0.18145161 & 0.17948718 & 0.16932324 & 16.932324 \\
\hline Brand & 0.05878511 & 0.03836317 & 0.13432836 & 0.06085193 & 0.05426357 & 0.06048387 & 0.12820513 & 0.07646873 & 7.646873 \\
\hline Color & 0.0457218 & 0.01534527 & 0.01492537 & 0.02028398 & 0.02325581 & 0.01209677 & 0.02564103 & 0.02246714 & 2.246714 \\
\hline Total & 1 & 1 & 1 & 1 & 1 & 1 & 1 & 1 & 100 \\
\hline
\end{tabular}

Source: The author(s) himself

The pair-wise comparison matrix in Table 5 is normalized by using Equation 2 and the respective priority vector (weightages) of each criterion is calculated using Equation 3 and shown in Table 6.

Consistency Calculation of the Main Criteria

$\left[\begin{array}{ccccccc}1 & 5 & 7 & 3 & 2 & 7 & 9 \\ 1 / 5 & 1 & 3 & 1 / 3 & 1 / 3 & 2 & 5 \\ 1 / 7 & 1 / 3 & 1 & 1 / 5 & 1 / 3 & 1 / 3 & 3 \\ 1 / 3 & 3 & 5 & 1 & 2 & 3 & 9 \\ 1 / 2 & 3 & 3 & 1 / 2 & 1 & 3 & 7 \\ 1 / 7 & 1 / 2 & 3 & 1 / 3 & 1 / 3 & 1 & 5 \\ 1 / 9 & 1 / 5 & 1 / 3 & 1 / 9 & 1 / 7 & 1 / 5 & 1\end{array}\right] *\left[\begin{array}{l}0.37656648 \\ 0.09394889 \\ 0.04528511 \\ 0.21594041 \\ 0.16932324 \\ 0.07646873 \\ 0.02246714\end{array}\right]=\left[\begin{array}{l}2.88725979 \\ 0.69881189 \\ 0.32291678 \\ 1.61999171 \\ 1.26995485 \\ 0.55385063 \\ 0.16166883\end{array}\right]$

The Weighted sum matrix $\left(W_{s}\right)$ is found out by multiplying the pair-wise decision matrix and the priority vector matrix (Row average matrix) as shown in Equation 5 and Equation 6. Now each elements of the Weighted sum matrix are divided by their respective priority vector to find out the consistency of each criterion as shown below.

$\left\{\begin{array}{l}2.88725979 / 0.37656648 \\ 0.69881189 / 0.09394889 \\ 0.32291678 / 0.04528511 \\ 1.61999171 / 0.21594041 \\ 1.26995485 / 0.16932324 \\ 0.55385063 / 0.07646873 \\ 0.16166883 / 0.02246714\end{array}\right\}=\left\{\begin{array}{c}7.66733082 \\ 7.43821359 \\ 7.13074965 \\ 7.50203116 \\ 7.50018067 \\ 7.24283786 \\ 7.19579048\end{array}\right\} \Rightarrow \begin{gathered}\text { Processor } \\ \text { Hard Disk Capacity } \\ \text { Operating System } \\ \text { RAM } \\ \text { Screen Size } \\ \text { Brand } \\ \text { Color }\end{gathered}$

Calculate the value of average consistency $\lambda_{\max }$ 
$=\frac{51.67713423}{7}$

$=7.38244775$, Hence $\lambda_{\max }=7.38244775$

Table 7: Checking of Consistency for the Main Criteria

\begin{tabular}{cc}
\hline No of Comparisons $(\mathbf{n})$ & $\mathbf{7}$ \\
\hline Average Consistency $\left(\lambda_{\max }\right)$ & 7.38244775 \\
\hline Consistency Index $(\mathrm{Cl})$ & 0.06374129 \\
\hline Randomly Generated Consistency Index (RI) & 1.32 \\
Consistency Ratio (CR) & 0.04828886 \\
\hline Consistent & YES \\
\hline
\end{tabular}

Source: The author(s) himself

By using Equation 7,

Consistency Index $(\mathrm{Cl})=\left(\lambda_{\max }-n\right) /(n-1)$

$=(7.38244775-7) /(7-1)$

$=0.06374129$

Randomly Generated Consistency Index (RI) value is found out from the Table 2. For $n=7$ the corresponding RI value is 1.32 .

By using Equation 8,

Consistency Ratio $(\mathrm{CR})=\mathrm{Cl} / \mathrm{RI}$

$=0.06374129 / 1.32$

$=0.04828886<0.1$

Since the value of consistency ratio (CR) value is less than 0.1 , so it can be concluded that the judgements of the decision maker are consistent and allows it to proceed further to the next step. The $\mathrm{Cl}$ and $\mathrm{CR}$ values are shown in Table 7 above. 


\section{Main Criteria}

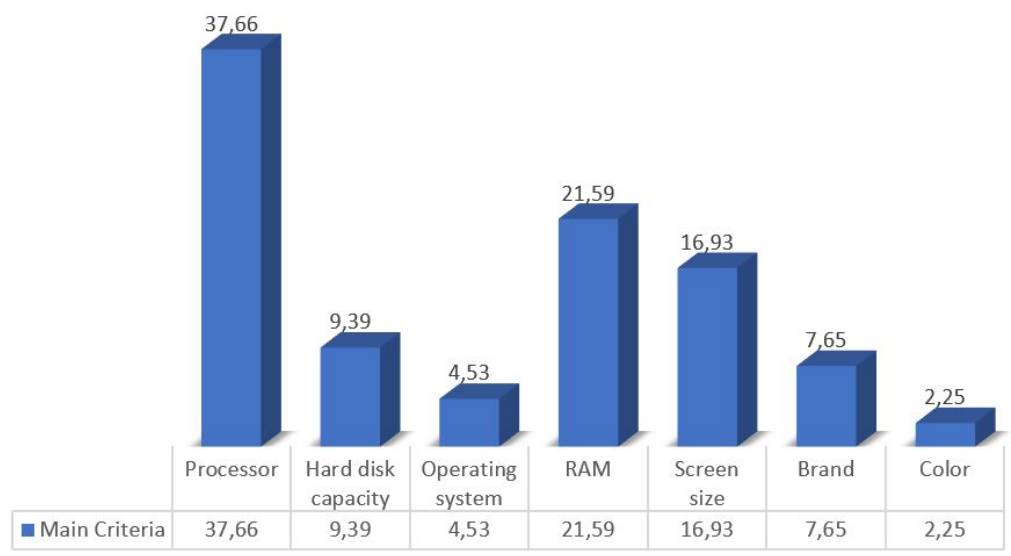

Figure 3: Graphical Representation of the criterion weightages Source: The author(s) himself

All the weightages of the criterion are calculated by using AHP technique and shown graphically in Figure 3. From Figure 3 it can be seen that processor is attained the highest weightage i.e. $37.66 \%$ indicating that it is the most preferable specification of a laptop model among the students followed by RAM (21.59\%) and screen size (16.93\%). Now using these weightages in WPM method which is shown in details in the next section.

\section{Calculation details of weighted product model (WPM)}

Table 8: Elements of the Evaluation Matrix

\begin{tabular}{lcccccccc}
\hline Models & Processor & $\begin{array}{c}\text { Hard Disk } \\
\text { Capacity }\end{array}$ & $\begin{array}{c}\text { Operating } \\
\text { System }\end{array}$ & RAM & Screen Size & Brand & Color \\
\hline Model 1 & 5 & 3 & 3 & 5 & 5 & 9 & 3 \\
\hline Model 2 & 7 & 9 & 5 & 5 & 7 & 3 & 3 \\
\hline Model 3 & 7 & 5 & 9 & 7 & 7 & 7 & 5 \\
\hline Model 4 & 3 & 5 & 9 & 3 & 3 & 2 & 9 \\
\hline Model 5 & 7 & 9 & 9 & 7 & 7 & 9 & 9 \\
\hline Model 6 & 5 & 3 & 5 & 5 & 7 & 5 & 3 \\
\hline
\end{tabular}

Source: The author(s) himself

The decision matrix is formed based on the relative choices and preferences of the common laptop users. From the market survey it is found that the 15 processor is mostly preferred by maximum people followed by 13 and 17 , so 15 is given the highest priority i.e. 7 followed by 13 i.e. 5 and 17 i.e. 3 . In the same way the most preferable sub-criteria under every main criteria column is allotted with the highest value followed by the rest in decreasing order. The decision (evaluation) matrix is shown in Table 8.

Table 9: Normalization of the Decision Matrix

\begin{tabular}{cccccccc}
\hline Weights $\left(\mathbf{w}_{\mathbf{j}}\right)$ & $\mathbf{0 . 3 7 6 5 6 6 4 8}$ & $\mathbf{0 . 0 9 3 9 4 8 8 9}$ & $\mathbf{0 . 0 4 5 2 8 5 1 1}$ & $\mathbf{0 . 2 1 5 9 4 0 4 1}$ & $\mathbf{0 . 1 6 9 3 2 3 2 3}$ & $\mathbf{0 . 0 7 6 4 6 8 7 3}$ & $\mathbf{0 . 0 2 2 4 6 7 1 4}$ \\
\hline Models & Processor & $\begin{array}{c}\text { Hard Disk } \\
\text { Capacity }\end{array}$ & $\begin{array}{c}\text { Operating } \\
\text { System }\end{array}$ & $\mathbf{R a m}$ & Screen Size & Brand & Color \\
\hline Model 1 & 0.71428571 & 0.33333333 & 0.33333333 & 0.71428571 & 0.71428571 & 1 & 0.33333333 \\
\hline Model 2 & 1 & 1 & 0.55555556 & 0.71428571 & 1 & 0.33333333 & 0.33333333 \\
\hline Model 3 & 1 & 0.55555556 & 1 & 1 & 1 & 0.777777778 & 0.55555556 \\
\hline
\end{tabular}


Table 9. Continued...

\begin{tabular}{cccccccc}
\hline Weights $\left(\mathbf{w}_{\mathbf{j}}\right)$ & $\mathbf{0 . 3 7 6 5 6 6 4 8}$ & $\mathbf{0 . 0 9 3 9 4 8 8 9}$ & $\mathbf{0 . 0 4 5 2 8 5 1 1}$ & $\mathbf{0 . 2 1 5 9 4 0 4 1}$ & $\mathbf{0 . 1 6 9 3 2 3 2 3}$ & $\mathbf{0 . 0 7 6 4 6 8 7 3}$ & $\mathbf{0 . 0 2 2 4 6 7 1 4}$ \\
\hline Model 4 & 0.42857143 & 0.55555556 & 1 & 0.42857143 & 0.42857143 & 0.22222222 & 1 \\
\hline Model 5 & 1 & 1 & 1 & 1 & 1 & 1 & 1 \\
\hline Model 6 & 0.71428571 & 0.33333333 & 0.55555556 & 0.71428571 & 1 & 0.55555556 & 0.33333333 \\
\hline
\end{tabular}

Source: The author(s) himself

All the criteria considered for this analysis is positive (maximization) in nature, hence by using the Equation 10 normalization of the decision matrix (Table 8) is done. The normalization matrix is shown in Table 9.

Table 10: Comparison of Model 1 with the other Models

\begin{tabular}{cl}
\hline $\mathbf{P}\left(\mathbf{A}_{1} / \mathbf{A}_{2}\right)$ & $\mathbf{0 . 7 9 7 7 0 7 3 8}$ \\
\hline$P\left(A_{1} / A_{3}\right)$ & 0.70727476 \\
\hline$P\left(A_{1} / A_{4}\right)$ & 1.46484918 \\
\hline$P\left(A_{1} / A_{5}\right)$ & 0.64792421 \\
\hline$P\left(A_{1} / A_{6}\right)$ & 0.96545280 \\
\hline
\end{tabular}

Source: The author(s) himself

By using Equation 12 finding the ratios, comparing each alternative with other alternatives. The comparison of Model 1 with other five models and their respective relative weightages are presented in the above Table 10 and one calculation is shown below.

Refer to Table 9: Comparing Model 1 with Model 2

For $P\left(A_{1} / A_{2}\right)$, Finding relative weightages between Model 1 and Model 2 according to Equation 12.

$\mathrm{P}\left(\mathrm{A}_{1} / \mathrm{A}_{2}\right)=\left(\frac{0.71428571}{1}\right)^{0.37656648} \times\left(\frac{0.33333333}{1}\right)^{0.09394889} \times\left(\frac{0.33333333}{0.55555556}\right)^{0.04528511} \times\left(\frac{0.71428571}{0.71428571}\right)^{0.21594041}$
$\times\left(\frac{0.71428571}{1}\right)^{0.16932323} \times\left(\frac{1}{0.333333333}\right)^{0.07646873} \times\left(\frac{0.33333333}{0.33333333}\right)^{0.02246714}$

$P\left(A_{1} / A_{2}\right)=0.79770738$

Table 11: Model Comparisons and Relative Weightages

\begin{tabular}{|c|c|c|c|c|c|c|c|}
\hline Model 2 & $\begin{array}{c}\text { Relative } \\
\text { Weightage }\end{array}$ & Model 3 & $\begin{array}{c}\text { Relative } \\
\text { Weightage }\end{array}$ & Model 4 & $\begin{array}{c}\text { Relative } \\
\text { Weightage }\end{array}$ & Model 5 & $\begin{array}{c}\text { Relative } \\
\text { Weightage }\end{array}$ \\
\hline$P\left(A_{2} / A_{3}\right)$ & 0.88663435 & $P\left(A_{3} / A_{4}\right)$ & 2.07111757 & $P\left(A_{4} / A_{5}\right)$ & 0.44231462 & $P\left(A_{5} / A_{6}\right)$ & 1.49007057 \\
\hline$P\left(A_{2} / A_{4}\right)$ & 1.83632397 & $P\left(A_{3} / A_{5}\right)$ & 0.91608559 & $P\left(A_{4} / A_{6}\right)$ & 0.65908000 & & \\
\hline$P\left(A_{2} / A_{5}\right)$ & 0.81223294 & $P\left(A_{3} / A_{6}\right)$ & 1.36503217 & & & & \\
\hline$P\left(A_{2} / A_{6}\right)$ & 1.21028441 & & & & & & \\
\hline
\end{tabular}

Source: The author(s) himself

Table 11 shows the comparisons among the laptop models and their respective relative weightages.

\section{RESULTS AND DISCUSSIONS}

All the laptop models are compared among each other and their respective relative weightages are found out which is shown in Table 10 and Table 11. 
From Table 10, if we consider the value $P\left(A_{1} / A_{4}\right)=1.46484918$, it indicates that the Model 1 is better than Model $4(M 1>M 4)$, since the value of $P\left(A_{1} / A_{4}\right)$ is greater than one (i.e. $1.46484918>1$ ). Similarly, for $P\left(A_{1} / A_{2}\right)=0.79770738$, it indicates that the Model 2 is better than Model $1(M 2>M 1)$ since its value $0.79770738<1$. In this way all the relative importance of each model with respect to other models are arranged from Table 10 and Table 11 and the following judgements is done which is given in Table 12 below.

Table 12: Judgements done Based on the Relative Weightages of the Laptop Models

\begin{tabular}{llllll}
\hline Model 1 & Model 2 & Model 3 & Model 4 & Model 5 & Model 6 \\
\hline$M 1<M 2$ & $M 2>M 1$ & $M 3>M 1$ & $M 4<M 1$ & $M 5>M 1$ & $M 6>M 1$ \\
\hline$M 1<M 3$ & $M 2<M 3$ & $M 3>M 2$ & $M 4<M 2$ & $M 5>M 2$ & $M 6<M 2$ \\
$M 1>M 4$ & $M 2>M 4$ & $M 3>M 4$ & $M 4<M 3$ & $M 5>M 3$ & $M 6<M 3$ \\
$M 1<M 5$ & $M 2<M 5$ & $M 3<M 5$ & $M 4<M 5$ & $M 5>M 4$ & $M 6>M 4$ \\
$M 1<M 6$ & $M 2>M 6$ & $M 3>M 6$ & $M 4<M 6$ & $M 5>M 6$ & $M 6<M 5$ \\
\hline
\end{tabular}

Source: The author(s) himself

From the above Table 12, if we consider the Model 5 column then it can be noted that Model 5 is superior than the all other 5 models, hence Model 5 comes first in the ranking order. Then, for Model 3 column, it is superior than all models except Model 5 so Model 3 comes second in the ranking order. In Model 2 column, it is only smaller than M3 and M5, hence it comes third in the ranking order. In Model 6 column, it is only smaller than the previous three models i.e. M5, M3 and M2, so it comes in the fourth position. Similarly, Model 1 is only greater than M4 so it comes before Model 4 and occupies the fifth position. Lastly, since Model 4 is inferior than all the other five models so it comes last in the ranking order. Furthermore, from Table 12 the ranking of all the six models is made as follows:

M5 > M3 > M2 > M6 > M1 > M4 (where the symbol " > " stands for "better than").

\section{CONCLUSION}

From the above analysis it can be concluded that Model 5 is the best laptop model followed by Model 3 and Model 2 among these 6 laptop models available in the market based on the views and opinions of the customers. The ranking order of the laptop models according to the choices and preferences of the laptop users is shown in Table 13. One who wish to buy the best available laptop model can go for Model 5 which have the following specifications: silver color 15.6-inch HP brand laptop with 15 processor, 1TB hard disk capacity, windows operating system and 8GB RAM. If this model is not available in the market one can go for Model 3 or Model 2. Since this paper highlighted the present scenario and market demand of the laptop model so, it will help the students to select the best model while purchasing a laptop and the laptop manufacturing companies can also modify their business strategies with respect to the present market demand.

\section{Limitations}

The outcome results and the ranking order of the alternatives might get changed when other MCDM tools like TOPSIS, PROMETHEE, VIKOR, ELECTRE etc. will be applied.

\section{Future Scope}

The same problem can also be solved by applying above mentioned MCDM methodologies e.g. TOPSIS, PROMETHEE, VIKOR, ELECTRE etc. and the final ranking order of the alternatives can be compared with these. Moreover, there are also other criteria like graphics card, display resolution, price etc. which can also be added along with these seven criterions in order to make the selection process more precise and accurate. 
These MCDM techniques can also be applied for choosing other household and electronic gadgets e.g. mobile, refrigerator, air conditioner, camera etc.

Table 13: Ranking Order of the Laptop Models

\begin{tabular}{cc}
\hline Laptop Models & Ranking \\
\hline Model 5 & Rank 1 \\
\hline Model 3 & Rank 2 \\
\hline Model 2 & Rank 3 \\
\hline Model 6 & Rank 4 \\
\hline Model 1 & Rank 5 \\
\hline Model 4 & Rank 6 \\
\hline
\end{tabular}

Source: The author(s) himself

\section{REFERENCES}

Adalı, E. and Işık, A. (2016), "Air conditioner selection problem with COPRAS and ARAS methods", Manas Journal of Social Studies, Vol. 5, No. 2, pp. 124-38, available at: https://pdfs.semanticscholar.org/b1 f9/9b4c8ff39137f5f1 f044df9572e5f62331 b3.pdf?_ga=2.4748531 .1193764185.1565108694-1821258113.1558350277 (accessed 10 February 2020).

Adalı, E. and Işık, A. (2017), "The multi-objective decision making methods based on MULTIMOORA and MOORA for the laptop selection problem", International Journal of Industrial Engineering, Vol. 13, No. 2, pp. 229-37. http://dx.doi.org/10.1007/s40092-016-0175-5.

Afshari, A., Mojaheed, M. and Yusuff, R.M. (2010), "Simple additive weighting approach to personnel selection problem", International Journal of Innovation, Management and Technology, Vol. 1, No. 5, pp. 511-5.

Araujo, F., Oliveira, V., Alvarez, D. et al. (2017), "Worker-recovered companies in brazil: Self-management process assessment by applying multi-criteria decision support tools", Brazilian Journal of Operations \& Production Management, Vol. 14, No. 2, pp. 249-64. http://dx.doi.org/10.14488/BJOPM.2017.v14.n2.a13.

Ayhan, M.B. (2013), "A fuzzy AHP approach for supplier selection problem: a case study in a gearmotor company", International Journal of Managing Value and Supply Chains, Vol. 4, No. 3, pp. 11-23. http://dx.doi.org/10.5121/ijmvsc.2013.4302.

Biswas, T. and Saha, P. (2019), "Selection of commercially available scooters by new MCDM method", International Journal of Data and Network Science, Vol. 3, No. 2, pp. 137-44. http://dx.doi.org/10.5267/j.ijdns.2018.12.002.

Bose, G. and Chatterjee, N. (2016), "Fuzzy hybrid MCDM approach for selection of wind turbine service technicians", Management Science Letters, Vol. 6, No. 1, pp. 1-18. http://dx.doi.org/10.5267/j.msl.2015.12.004.

Bridgman, P.W. (1922), Dimensional Analysis, Yale University Press, New Haven, Connecticut, USA.

Cavalcante, C.A. and Costa, A.P. (2010), "Multicriteria model of preventive maintenance", Brazilian Journal of Operations \& Production Management, Vol. 3, No. 1, pp. 71-86, available at: https://bjopm.emnuvens.com.br/bjopm/article/view/32/pdf_28 (accessed 10 February 2020).

Chaghooshi, A., Arab, A. and Dehshiri, S. (2016), "A fuzzy hybrid approach for project manager selection", Decision Science Letters, Vol. 5, No. 3, pp. 447-60. http://dx.doi.org/10.5267/j.dsl.2016.1.001.

Climaco, J.C., Soares de Mello, J.C. and Meza, L. (2010), "A study of highways performance with a molpdea model and an interactive tri-criteria linear programming package (Trimap)", Brazilian Journal of Operations \& Production Management, Vol. 7, No. 1, pp. 163-79, available at: https://bjopm.emnuvens.com.br/bjopm/article/view/V7N1A8/bjopm_91 (accessed 10 February 2020).

Costa, H. (2017), "AHP-De Borda: a hybrid multicriteria ranking method", Brazilian Journal of Operations \& Production Management, Vol. 14, No. 3, pp. 281-7. http://dx.doi.org/10.14488/BJOPM.2017.v14.n3.a1.

Costa, H., Nepomuceno, L. and Pereira, V. (2018), "ELECTRE ME: a proposal of an outranking modeling in situations with several evaluators", Brazilian Journal of Operations \& Production Management, Vol. 15, No. 4, pp. 566-75. http://dx.doi.org/10.14488/BJOPM.2018.v15.n4.a10. 
Costa, J.F.S. (2011), "A genetic algorithm to obtain consistency in analytic hierarchy process", Brazilian Journal of Operations \& Production Management, Vol. 8, No. 1, pp. 55-64. http://dx.doi.org/10.4322/bjopm.2011.003.

Costa, L. and Amato Neto, J. (2017), "Proposal for a water resource management strategy model using the water footprint concept", Brazilian Journal of Operations \& Production Management, Vol. 14, No. 3, pp. 371-80. http://dx.doi.org/10.14488/BJOPM.2017.v14.n3.a10.

Dey, S. and Chakraborty, S. (2016), "A study on the machinability of some metal alloys using grey TOPSIS method", Decision Science Letters, Vol. 5, No. 1, pp. 31-44. http://dx.doi.org/10.5267/j.dsl.2015.9.002.

Donizetti de Lima, J., Bennemann, M., Puttow Southier, L. et al. (2017), “\$AV€: web system to support the teaching and learning process in engineering economics", Brazilian Journal of Operations \& Production Management, Vol. 14, No. 4, pp. 469-85. http://dx.doi.org/10.14488/BJOPM.2017.v14.n4.a4.

Duckstein, L. and Opricovic, S. (1980), "Multi objective optimization in river basin development", Water Resources Research, Vol. 16, No. 1, pp. 14-20. http://dx.doi.org/10.1029/WR016i001 p00014.

Durán, O. and Aguilo, J. (2008), "Computer-aided machine tool selection based on a Fuzzy-AHP approach", Expert Systems with Applications, Vol. 34, No. 3, pp. 1787-94. http://dx.doi.org/10.1016/j.eswa.2007.01.046.

Efendigil, T., Önüt, S. and Kongar, E. (2008), "A holistic approach for selecting a third-party reverse logistics provider in the presence of vagueness", Computers \& Industrial Engineering, Vol. 54, No. 2, pp. 269-87. http://dx.doi.org/10.1016/j.cie.2007.07.009.

Endler, K., Scarpin, C. and Arns Steiner, M. (2017), "Proposed system for analyzing the location of preschools: a Brazilian case study", Brazilian Journal of Operations \& Production Management, Vol. 14, No. 4, pp. 446-60. http://dx.doi.org/10.14488/BJOPM.2017.v14.n4.a2.

Fishburn, P.C. (1967), Additive Utilities with Incomplete Product Set: Applications to Priorities and Assignments, Operations Research Society of America, Baltimore, USA.

Geldermann, J., Spengler, T. and Rentz, O. (2000), "Fuzzy outranking for environmental assessment: case study: iron and steel making industry", Fuzzy Sets and Systems, Vol. 115, No. 1, pp. 45-65. http://dx.doi.org/10.1016/S0165-0114(99)00021-4.

Goswami, S.S. and Mitra, S. (2020), "Selecting the best mobile model by applying AHP-COPRAS and AHPARAS decision making methodology", International Journal of Data and Network Science, Vol. 4, No. 1, pp. 27-42. http://dx.doi.org/10.5267/j.ijdns.2019.8.004.

Grillo, H., Mula, J., Martínez, S. et al. (2018), "Key parameters for the analysis stage of internationalization of operations", Brazilian Journal of Operations \& Production Management, Vol. 15, No. 2, pp. 173-81. http://dx.doi.org/10.14488/BJOPM.2018.v15.n2.a1.

Hernández, C., Marins, F.A., Rocha, P. et al. (2010), "Using AHP and ANP to evaluate the relation between reverse logistics and corporate performance in Brazilian industry", Brazilian Journal of Operations \& Production Management, Vol. 7, No. 2, pp. 47-62, available at: https://bjopm.emnuvens.com.br/bjopm/article/view/V7N2A3_/V7N2A3 (accessed 10 February 2020).

Hofmann, E. (2011), "Compensation and buy-back deals in supply chains: analyzing strategic decision areas by using AHP", Brazilian Journal of Operations \& Production Management, Vol. 8, No. 2, pp. 17-49. http://dx.doi.org/10.4322/bjopm.2012.002.

Hwang, C.L. and Yoon, K. (1981), Multiple Attributes Decision Making Methods and Applications, Springer, Berlin.

Işık, A. and Adalı, E. (2016), "A comparative study for the agricultural tractor selection problem", Decision Science Letters, Vol. 5, No. 4, pp. 569-80. http://dx.doi.org/10.5267/j.dsl.2016.3.002.

Kandakoglu, A., Celik, M. and Akgun, I. (2009), "A multi-methodological approach for shipping registry selection in maritime transportation industry", Mathematical and Computer Modelling, Vol. 49, No. 34, pp. 586-97. http://dx.doi.org/10.1016/j.mcm.2008.09.001.

Karande, P., Zavadskas, E.K. and Chakraborty, S. (2016), "A study on the ranking performance of some MCDM methods for industrial robot selection problems", International Journal of Industrial Engineering Computations, Vol. 7, pp. 399-422. http://dx.doi.org/10.5267/j.ijiec.2016.1.001.

Koganti, V., Menikonda, N., Anbuudayasankar, S. et al. (2019), "GRAHP TOP model for supplier selection in Supply Chain: a hybrid MCDM approach", Decision Science Letters, Vol. 8, No. 1, pp. 65-80. http://dx.doi.org/10.5267/j.dsl.2018.5.002.

Kowalski, K., Stagl, S., Madlener, R. et al. (2009), "Sustainable energy futures: methodological challenges in combining scenarios and participatory multi-criteria analysis", European Journal of Operational Research, Vol. 197, No. 3, pp. 1063-74. http://dx.doi.org/10.1016/j.ejor.2007.12.049. 
Kundakcı, N. and Tuş Işık, A. (2016), "Integration of MACBETH and COPRAS methods to select air compressor for a textile company", Decision Science Letters, Vol. 5, No. 3, pp. 381-94. http://dx.doi.org/10.5267/j.dsl.2016.2.003.

Lee, A.H.I., Chen, W.C. and Chang, C.J. (2008), "A fuzzy AHP and BSC approach for evaluating performance of IT department in the manufacturing industry in Taiwan", Expert Systems with Applications, Vol. 34, No. 1, pp. 96-107. http://dx.doi.org/10.1016/j.eswa.2006.08.022.

MacCrimon, K.R. (1968), Decision Making Among Multiple Attribute Alternatives: a Survey and Consolidated Approach, RM-4823-ARPA, Rand Corporation, Santa Monica, available at: https://www.rand.org/pubs/research_memoranda/RM4823.html (accessed 10 February 2020).

Marzouk, M. and Abdelakder, E. (2019), "On the use of multi-criteria decision making methods for minimizing environmental emissions in construction projects", Decision Science Letters, Vol. 8, No. 4, pp. 373-92. http://dx.doi.org/10.5267/j.dsl.2019.6.002.

Melón, M.G., Aragonés Beltran, P. and González Cruz, M.C. (2008), "An AHP-based evaluation procedure for innovative educational projects: A face-to-face vs computer-mediated case study", Omega, Vol. 36, No. 5, pp. 754-65. http://dx.doi.org/10.1016/j.omega.2006.01.005.

Miller, D.W. and Starr, M.K. (1969), Executive Decisions and Operations Research. Prentice-Hall, Englewood Cliffs, New Jersey.

Mitra, S. and Goswami, S.S. (2019a), "Selection of the desktop computer model by AHP-TOPSIS hybrid MCDM methodology", International Journal of Research and Analytical Reviews, Vol. 6, No. 1, pp. 78490, available at: http://doi.one/10.1729/Journal.19551 (accessed 10 February 2020).

Mitra, S. and Goswami, S.S. (2019b), "Application of simple average weighting optimization method in the selection of best desktop computer model", Advanced Journal of Graduate Research, Vol. 6, No. 1, pp. 60-8. http://dx.doi.org/10.21467/ajgr.6.1.60-68.

Mitra, S. and Kundu, S. (2017), "Application of analytic hierarchy process for domestic refrigerator selection", International Journal of Emerging Technologies in Engineering Research, Vol. 5, No. 12, pp. 126-32, available at: http://www.ijeter.everscience.org/Manuscripts/Volume-5/Issue-12/Vol-5-issue12-M-21.pdf (accessed 10 February 2020).

Mitra, S. and Kundu, S. (2018), "Application of TOPSIS for best domestic refrigerator selection", International Journal of Research and Analytical Reviews, Vol. 5, No. 3, pp. 226-31, available at: https://ijrar.com/upload_issue/ijrar_issue_1212.pdf (accessed 10 February 2020).

Moraes Vieira, J., Simões Gomes, C. and Engel Braga, I. (2017), "Development of a scenario prospecting model with the use of multicriteria decision aiding: Importance of environmental variables", Brazilian Journal of Operations \& Production Management, Vol. 14, No. 2, pp. 210-7. http://dx.doi.org/10.14488/BJOPM.2017.v14.n2.a9.

Nery, V. (2017), "Classification of R\&D infrastructure models in basic business incubators technology in the state of Paraná", Brazilian Journal of Operations \& Production Management, Vol. 14, No. 2, pp. 23948. http://dx.doi.org/10.14488/BJOPM.2017.v14.n2.a12.

Podgórski, D. (2015), "Measuring operational performance of OSH management system: a demonstration of AHP-based selection of leading key performance indicators", Safety Science, Vol. 73, pp. 146-66. http://dx.doi.org/10.1016/j.ssci.2014.11.018.

Prasad, K. and Chakraborty, S. (2018), "Application of the modified similarity-based method for cutting fluid selection", Decision Science Letters, Vol. 7, No. 3, pp. 273-86. http://dx.doi.org/10.5267/j.dsl.2017.8.002.

Prasad, K., Subbaiah, K. and Prasad, M. (2017), "Supplier evaluation and selection through DEA-AHP-GRA integrated approach: a case study", Uncertain Supply Chain Management, Vol. 5, No. 4, pp. 369-82. http://dx.doi.org/10.5267/j.uscm.2017.4.001.

Qin, X.S., Huang, G.H., Chakma, A. et al. (2008), "A MCDM-based expert system for climate change impact assessment and adaptation planning: a case study for the georgia basin, Canada", Expert Systems with Applications, Vol. 34, No. 3, pp. 2164-79. http://dx.doi.org/10.1016/j.eswa.2007.02.024.

Quezada, L., O'Brien, C., Córdova, F. et al. (2006), "Conceptual model for the generation of performance measures in manufacturing firms", Brazilian Journal of Operations \& Production Management, Vol. 3, No. 2, pp. 21-34, available at: https://bjopm.emnuvens.com.br/bjopm/article/view/BJV3N1_2006_P2/pdf_24 (accessed 10 February 2020).

Rathi, R., Khanduja, D. and Sharma, S. (2016), "A fuzzy MADM approach for project selection: a six sigma case study", Decision Science Letters, Vol. 5, No. 2, pp. 255-68. http://dx.doi.org/10.5267/j.dsl.2015.11.002. 
Reis, A.C., Souza, C.G., Costa, N.N. et al. (2017), "Warehouse design: a systematic literature review", Brazilian Journal of Operations \& Production Management, Vol. 14, No. 4, pp. 542-55. http://dx.doi.org/10.14488/BJOPM.2017.v14.n4.a10.

Resende de Carvalho, E., Mota, A.E.A.S., Martins, G.M.S. et al. (2017), "The current context of lean and six sigma logistics applications in literature: a systematic review", Brazilian Journal of Operations \& Production Management, Vol. 14, No. 4, pp. 586-602. http://dx.doi.org/10.14488/BJOPM.2017.v14.n4.a14.

Roy, B. (1968), "Classement et choix en présence de points de vue multiples: la méthode ELECTRE", La Revue d'Informatique et de Recherche Opérationelle, Vol. 8, pp. 57-75.

Saaty, T.L. (1980), The Analytic Hierarchy Process, McGraw-Hill, New York.

Saaty, T.L. (2008), Decision Making for Leaders: the Analytic Hierarchy Process for Decisions in a Complex World, RWS Publications, Pennsylvania.

Saisse, R. and Lima, G. (2019), "Similarity modeling with ideal solution for comparative analysis of projects in the context of the additional brics proposal", Brazilian Journal of Operations \& Production Management, Vol. 16, No. 4, pp. 659-71. http://dx.doi.org/10.14488/BJOPM.2019.v16.n4.a11.

Salomon, V. and Whitaker, R. (2007), "Decision-making considering dependence relations for the improvement of production management", Brazilian Journal of Operations \& Production Management, Vol. 4, No. 2, pp. 47-60, available at: https://bjopm.emnuvens.com.br/bjopm/article/view/BJV4N2_2007_P3/BJOPMV4N2P3 (accessed 10 February 2020).

Santis, R., Golliat, L. and Aguiar, E. (2017), "Multi-criteria supplier selection using fuzzy analytic hierarchy process: case study from a Brazilian railway operator", Brazilian Journal of Operations \& Production Management, Vol. 14, No. 3, pp. 428-37. http://dx.doi.org/10.14488/BJOPM.2017.v14.n3.a15.

Saracoglu, B.O. (2013), "Selecting industrial investment locations in master plans of countries", European Journal of Industrial Engineering, Vol. 7, No. 4, pp. 416-41. http://dx.doi.org/10.1504/EJIE.2013.055016.

Sari, D.P., Wijayanti, W.R., Prayogo, A. et al. (2018), "An integrated fuzzy AHP and TOPSIS model for evaluating the performance of raw material suppliers: a case study in lasem batik writing centre", MATEC Web of Conferences, Vol. 204, pp. 02014. http://dx.doi.org/10.1051/matecconf/201820402014.

Sri Krishna, S., Sri Nivasulu Readdy, A. and Vani, S. (2014), "A new car selection in the market using TOPSIS", International Journal of Engineering Research and General Science, Vol. 2, No. 4, pp. 17781, available at: http://ijergs.org/files/documents/A-NEW20.pdf (accessed 10 February 2020).

Tofallis, C. (2014), "Add or multiply? A tutorial on ranking and choosing with multiple criteria", INFORMS Transactions on Education, Vol. 14, No. 3, pp. 109-19. http://dx.doi.org/10.1287/ited.2013.0124.

Triantaphyllou, E. (2000), "Multi-criteria decision making: a comparative study", Applied Optics, Vol. 44, pp. 5-21. http://dx.doi.org/10.1007/978-1-4757-3157-6_2.

Triantaphyllou, E. and Mann, S.H. (1989), "An examination of the effectiveness of multidimensional decision making methods: A decision-making paradox", Journal of Decision Support Systems, Vol. 5, No. 3, pp. 303-12. http://dx.doi.org/10.1016/0167-9236(89)90037-7.

Triantaphyllou, E. and Mann, S.H. (1995), "Using the analytic hierarchy process for decision making in engineering applications: Some challenges", International Journal of Industrial Engineering: Theory, Applications and Practice, Vol. 2, No. 1, pp. 35-44.

Tsoutsos, T., Drandaki, M., Frantzeskaki, N. et al. (2009), "Sustainable energy planning by using multi-criteria analysis application in the island of crete", Energy Policy, Vol. 37, No. 5, pp. 1587600. http://dx.doi.org/10.1016/j.enpol.2008.12.011.

Tzeng, G.H., Lin, C.W. and Opricovic, S. (2005), "Multi-criteria analysis of alternative-fuel buses for public transportation", Energy Policy, Vol. 33, No. 11, pp. 1373-83. http://dx.doi.org/10.1016/j.enpol.2003.12.014.

Vaillancourt, K. and Waaub, J.P. (2004), "Equity in international greenhouse gases abatement scenarios: A multi criteria approach", European Journal of Operational Research, Vol. 153, No. 2, pp. 489-505. http://dx.doi.org/10.1016/S0377-2217(03)00170-X.

Venkateswarlu, P. and Sarma, B.D. (2016), "Selection of supplier by using SAW and VIKOR methods", International Journal of Engineering Research and Applications, Vol. 6, No. 9, pp. 808. 
Wu, C.R., Lin, C.T. and Lin, Y.F. (2009), "Selecting the preferable bank assurance alliance strategic by using expert group decision technique", Expert Systems with Applications, Vol. 36, No. 2, pp. 3623-9. http://dx.doi.org/10.1016/j.eswa.2008.02.016.

Author contributions: All the authors contributed equally to this paper. 